\title{
Analytic Sentences, Cognition, and Language: Some Links between Current Theories
}

\author{
Analitiniai sakiniai, pažinimas ir kalba: \\ šiuolaikinių teorijų sąsajos
}

\section{SAL $35 / 2019$}

Analytic Sentences, Cognition, and

Language: Some

Links between

Current Theories

Received 06/2019

Accepted 10/2019

\section{LINGUISTICS / KALBOTYRA}

\section{Miguel López-Astorga}

University of Talca, Chile

\author{
Erossef http://dx.doi.org/10.5755/j01.sal.0.35.23516
}

This paper tries to explore possible relations and differences between three kinds of contemporary theories about cognition and language: the approaches supporting the idea that there is a mental logic, the mental models theory, and the frameworks based upon probability logic. That exploration is made here by means of the analytic sentences and the revision of the way each of those types of theories can deal with them. The conclusions seem to show that the three kinds of theories address such sentences in a similar manner, which can mean that there can be more links between them than thought. Thus, it is argued, as a possibility, that the three theories can be accepted at the same time, and that it can be assumed that their differences refer just to the fact that they deal with different aspects of language and cognition. From other points of view, this has already been raised in the literature with regard to the three mentioned theories (especially, with regard to the approaches supporting a mental logic and the mental models theory). However, the point here is double: on the one hand, the link between these theories is now presented from another perspective (the one of the analytic sentences). On the other hand, the paper provides relations between the three frameworks at once from that very perspective and in a systematic way.

KEYWORDS: analytic sentences, probability logic, reasoning, semantic mental models, syntactic mental logic.

What the analytic sentences are is well known by philosophers. From Kant, many thinkers have resorted to that concept, which keeps being present currently in most of the philosophical branches. However, it will be revised here from a perspective especially cognitive and linguistic, since the main goal of this paper is to use it in order to detect similarities and differences between three theories about the human mind that, in principle, appear to be incompatible.

As indicated below, some links between those theories have already been pointed out in the specialized literature. Nevertheless, analytic sentences will be taken into account here to better see to what extent the three theories, which can be currently considered to be the three most important frameworks about cognition, are really inconsistent.

In this way, the first section will explain in more detail what the analytic sentences are exactly. Then, the three next sections will be devoted, respectively, to the manner each of the three theories addresses the analytic sentences. Those theories, which are actually, as also

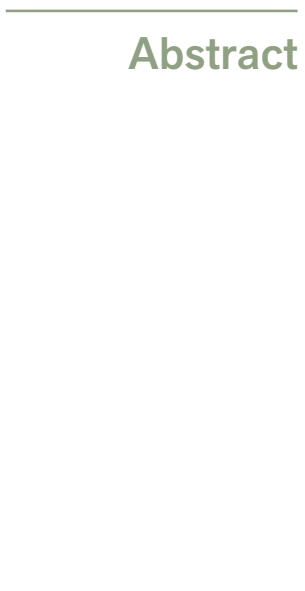

Introduction

ktu

Research Journal Studies about Languages No. 35/2019, pp. 61-69 ISSN 1648-2824 (print) ISSN 2029-7203 (online) DOl.org/10.5755/j01.sal.35.0.23516 
The Analytic Sentences shown below, groups or kinds of theories, are usually known as the approaches supporting a mental logic, the mental models theory, and the frameworks based upon probability logic. And thus, lastly, a final section will try to consider the differences that can be noted and the relationships that can be provided between the three aforementioned types of theories.

As said, Kant (1998) used the expression 'analytic sentences' to refer to a certain particular kind of sentences. Such sentences were those that included its predicate into its subject, which means that just knowing the subject was possible to state the predicate.

There is no doubt that, if defined in that way, it seems that many other philosophers have referred to this notion both before and after Kant. Clearly, before him, for example, Sextus Empiricus, in Pyrroniae Hypotyposes 2.112, speaks about some thinkers that claim that a conditional is only true when its consequent can be derived from its antecedent (for a developed analysis, see e.g., O'Toole \& Jennings, 2004, pp. 476ff). Likewise, after him, works such as, for example, the ones of Braine and O'Brien (1998a) or Récanati (2000) seem to hold something similar (for a clearer account, see e.g., Douven, Elqayam, Singmann, \& Wijnbergen-Huitink, 2018). Nonetheless, beyond the fact that both Sextus Empiricus and Récanati or Braine and O'Brien really talk about conditionals, and not about every type of a possible analytic sentence, it is obvious that the idea of analytic sentences most of times leads to think about Kant.

In any case, what is absolutely evident is that it is hard to discuss that, if the account given by Kant is assumed, an analytic sentence is a sentence difficult to deny and that most people should accept. Thus, it can be said that a sentence of that kind is, for example, this one:

\section{[I] Belgium is in Europe}

Indeed, the concept of Belgium includes that of Europe. So, if 'Belgium' (the subject) is said, it is not necessary to say that it is in Europe, because general knowledge gives individuals the information that Belgium is in Europe. And something similar can be said regarding examples such as these ones:

[l.b] Snow is white

[l.c] A hexagon has six sides

[I.d] A rabbit is a mammal

[l.e] A fish needs water to live

However, [l], [l.b], [l.c], [l.d], and [l.e.] will not be the examples that will be used in this paper to review the frameworks of the theories that will be considered. Instead, a conditional version of [I] will be chosen for that aim, the reason being obvious: beyond the fact that the version, as it can be noted below, can be considered as representative enough, although, probably, a sentence such as [I] could be understood without difficulties under the approaches that will be revised, the conditional form makes that task easier, since such approaches are often proposed to explain reasoning in general and conditional reasoning in particular. So, the sentence will be as follows:

[II] If I am in Belgium, then I am in Europe

Certainly, the way a conditional sentence such as [II] can be understood from the three types of theories indicated above is very easy to show. Exactly that is done in the next sections. 
As mentioned, a first kind of theories can be the one corresponding to those claiming that a logic in the human mind really exists. The problem here is that, as also pointed out, there is not only one framework proposing that idea, but several ones. Some examples can be the proposal of the mental logic theory (e.g., Braine \& O'Brien, 1998b), the theory raised by Rips (e.g., Rips, 1994), or the theses presented by Henlé (e.g., Henlé, 1962).

So, it is difficult to take all of the specificities that make theories such as those different into account at the same time. However, what is possible is to think about a general and idealized framework considering only what such theories have in common. In this way, a point to pay attention to is that those theories are essentially syntactic and based upon formal schemata. Of course, they do not always accept all of the rules that can be applied in classical logic, but some of the requirements of this last logic can be assumed in this section, and that simply because they correspond to the set of requirements of classical logic that is accepted by most of the approaches supporting a mental logic. Thus, it can be said, for example, that most of such approaches would deem [II] as a conditional sentence, whether they interpret the conditional in a material manner (i.e., as classical logic does) or not (the mental logic theory, for instance, explicitly rejects the material interpretation of the conditional; see e.g., Braine \& O'Brien, 1998a). Accordingly, it could be said that, under this perspective, the logical form that could be attributed to [II] would be as follows:

$$
\text { [III] } p \rightarrow q
$$

Where, evidently, ' $p$ ' would stand for the fact that I am in Belgium, ' $q$ ' would represent the fact that I am in Europe, and ' $\rightarrow$ ' would denote conditional relationship (again, whether or not that relationship is materially understood).

But these theories often admit that, if a formula such as [III] is true, it is not even absolutely necessary to assume the truth table that classical logic assigns to the conditional to clearly note, at once, that this formula is true too:

[IV] $\neg(p \wedge \neg q)$

Where, obviously, ' $\neg$ ' is negation and "expresses conjunction.

And this allows coming to a conclusion in this particular case, since this kind of theories usually proposes that reasoning is never made in a vacuum, and that pragmatics and general knowledge also play a role in the intellectual activity. In this way, it can be stated that the people with minimal cultural formation know, as indicated above, that Belgium is a country in Europe, that it is impossible to be in Belgium and not in Europe, and that hence [II], [III], and [IV] are undoubtedly true, as, given the previous equivalences, this formula, which is exactly the opposite one of [IV] and, therefore, inconsistent with [III], is not possible:

\section{[V] $p \wedge \neg q$}

There is, accordingly, a contradiction between [IV] and [V] which reveals that the original sentence, that is, [II], and even [I], is absolutely true, as well as that it cannot be said that the theories supporting a mental logic do not have enough resources to explain how the human mind understands analytic sentences.

The case of the mental models theory is different from the one of the theories addressed in the previous section in at least two senses. On the one hand, it does not actually refer to a group of theories, but just to the same theory, which has had several versions over time (this fact can be noted if the literature on it is chronologically revised, and the last version of

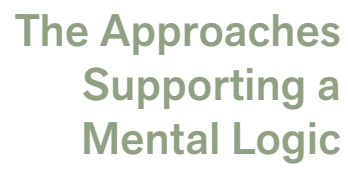


this framework can be possibly that presented in papers such as Khemlani, Byrne, \& Johnson-Laird's, 2018). On the other hand, the mental models theory is not syntactic, but basically semantic (see e.g., Oakhill \& Garnham, 1996).

However, beyond these points, for the goals here, it can be stated that this theory proposes that individuals tend to represent what sentences transmit in an iconic way (e.g., Johnson-Laird, Khemlani, \& Goodwin, 2015, p. 202). Thus, from any sentence, people generate symbolic models describing the feasible relationships that can exist between their clauses (see e.g., Johnson-Laird, 2012, pp. 134-145). And this, for the case of a conditional such as [II], which is the case mainly interesting in this paper, means that three symbolic models can be built from it:

[VI] [l am in Belgium] \& [l am in Europe]

[VII] Not-[l am in Belgium] \& [l am in Europe]

[VIII] Not-[I am in Belgium] \& Not-[l am in Europe]

As said, [VI], [VII], and [VIII] are iconic models representing the world, or rather different possible situations in the world. In this way, in [VI], I am in Belgium and, accordingly, in Europe. In [VII], the world is not very different, the only change being that, although I keep being in Europe, I am not in Belgium. And, in [VIII], only one more circumstance is modified: not only I am not in Belgium, I am not in Europe either.

But one might think that a model is missing because one more combination would be possible. Clearly, that combination would be the following:

[IX] [I am in Belgium] \& Not-[I am in Europe]

Nevertheless, what actually happens is that models such as [IX] can be the key to understand how the mental models theory deals with analytic sentences. A conditional such as [II] refers to models such as [VI], [VII], and [VIII], since [II] can be true in all of those three possible situations. I would only be false if [IX] were possible, as this last model represents a situation in which the conditional [II] is not true. Nonetheless, as in the theories supporting a mental logic, pragmatics and general knowledge are important here too, and, by virtue of pragmatics or general knowledge, people can know, following the mental models theory, that certain combinations between the clauses of a sentence are not possible, and that hence certain models cannot be constructed (see e.g., Johnson-Laird et al., 2015, p. 202). And this is exactly what occurs with [IX]. Individuals know for sure that it can be accepted in no way, and that, accordingly, [II] is absolutely true, since a situation in which somebody is in Belgium and not in Europe, that is, a situation in which it is false, is not even conceivable. So, there is no doubt that the mental models theory can also describe the mental processes that are often linked to the understanding of analytic sentences.

Lastly, a final set of theories can be the one of the frameworks more or less directly based on

The Frameworks Based upon Probability Logic probability logic. There are also a number of approaches that can be included in this set, and to name all of them can be an excessively long work beyond the goals of this paper. For that reason, perhaps it can be enough to indicate that this perspective seems to come from works such as the one of Wason (1966), who proposed a 'defective' truth table in which the cases in which the antecedent of the conditional was false were not considered, the one of Ramsey (1931), who spoke about a test in which hypothetical situations in which the antecedent was true were thought and the possibility of the consequent being true in those very situations was revised, or the one of Adams (1975), who clearly linked the interpretation of the conditional to formulae based upon probability rules (for a more developed description of these points and 
this general framework, see, e.g., papers such as that of Evans, Handley, \& Over, 2003, pp. 321-335; or that of Over, Hadjichristidis, Evans, Handley, \& Sloman, 2007, pp. 62-97).

That said, this section, for the sake of simplicity and clarity, will be mainly devoted to just one of the frameworks that can be deemed as part of this group of theories, assuming that the account that will be offered will not be hard to adapt to get similar explanations under the other frameworks that could also be considered as belonging to this kind of approaches. Thus, the framework chosen will be the so-called 'delta-probability' framework, a framework explained in detail in works such as, for example, the one of Over et al. (2007, pp. 62-97), who refer to books such as that of Bennet (2003).

The basic idea of the delta-probability approach (subsequently, $\delta-p$ ) is that people tend to interpret that the probability of a conditional matches a formula with a subtraction. The first element in that subtraction is the percentage corresponding to the probability that the consequent happens given the antecedent, and the second element, which is the one that should be subtracted from the first one, is the percentage corresponding to the probability that the consequent occurs without the antecedent. Thus, for [II], the formula should be akin to this one:

$[X] \quad \delta-p[I I]=P(I$ am in Europe $\mid I$ am in Belgium $)-P(I$ am in Europe $\mid \mathrm{I}$ am not in Belgium $)$

Where, of course, ' $\delta-p[a]$ ' refers to the delta-probability of $a$ and ' $P(a \mid \beta)$ ' stands for the probability of a given $\beta$.

From $[\mathrm{X}]$, one might assume that $\mathrm{P}(\mathrm{I}$ am in Europe $\mid \mathrm{I}$ am in Belgium), that is, the first element in the subtraction, is equal to 1 , that is, to the maximum possible probability. Likewise, one might also assume that $\mathrm{P}(\mathrm{I}$ am in Europe | I am not in Belgium) should be necessarily lower, since the possibility exists to be in many places around the world that are not in Europe. So, a priori, it can be thought that the result of $[X]$ has to be positive, which, under $\delta-p$, means that the probability that I am in Europe given that I am in Belgium is higher (in fact, as said, it is the highest possible probability) than the probability that I am just in Europe, and reveals that there is really a connection between being in Belgium and being in Europe (analyses regarding this idea of the connection between the two clauses can be found in other works too, and one of them is clearly Krzyzanowska, Collins, \& Hahn, 2017, pp. 199-205).

Accordingly, how the human mind works when faced to analytic sentences can be described from this perspective as well. Actually, that can be seen in an obvious way simply, and hence without needing further explanation, from the very fact that $\delta$-p can provide equivalences such as this one:

[XI] $\mathrm{P}(\mathrm{I}$ am in Europe $\mid \mathrm{I}$ am in Belgium $)=1$

Indeed, it is evident that, if an equivalence such as [XI] is correct, a sentence such as [II] can never be false. So, the possibilities of $\delta$ - $p$ with regard to the issue addressed in this paper are absolutely clear. Furthermore, although there is no doubt that, as stated, $\delta-p$ is only one of the possible frameworks that can be included in the general perspective related to probability logic, it is true too, as also claimed, that the explanation presented could be adapted to any other framework belonging to the aforementioned perspective without many difficulties.

But maybe there are more relationships between these types of theories than thought. Perhaps, as, for instance, López-Astorga (2015, pp. 141-149) states about the links that can exist between the approaches supporting the idea that there is a mental logic and the mental models theory, these three perspectives really address the same phenomenon but from different points of view. Thus, it can be thought that they focus on different aspects of the intellectual activity and language that are really always joined, and that they only consider that aspect and build all its discourse based upon it.

Relationships between the Three Kinds of Theories 
In fact, the link between the theories supporting a mental logic and the mental models theory is very easy to see. As indicated, López-Astorga (2015, pp. 141-149) points out relations in this way. His general idea is that the iconic models of the mental models are clearly consistent with the truth tables of classical logic, which is something that, at least in a sense, the mental logic theory already seems to suggest (see, e.g., Braine \& O'Brien, 1998b). If this point is assumed, it is obvious that well-formed logical formulae can be constructed from the models. For example, it can be thought that [VI], [VII], and [VIII] match the cases in which the conditional is valid in its classical truth table, and thus that this fact allows attributing a syntactic form such as [III] to those semantic models. This, given that, as mentioned, both the theories supporting a mental logic and the mental models theory admit the role played by pragmatics and general knowledge, would enable to link the aspects that are still separated: syntax (the aspect highlighted by the theories supporting the idea of a mental logic) and semantics (the aspect highlighted by the mental models theory).

However, another way to relate the theories supporting a mental logic to the mental models theory, and, therefore, syntax to semantics, proposed, for example, in López-Astorga (2018, pp. 120-136), is to resort to modal logic and system K. In this case, the idea is to consider models such as [VI], [VII], and [VIII] -or even [IX]- to be sets of possible worlds (in the sense that they have in system $\mathrm{K}$, and not in the one given in papers such as, for example, those of Stalnaker, 1968, 1975). Because the mental models theory deems its iconic models as possibilities, López-Astorga (2018) thinks that to do so is justified, and the result is that the models of the mental models theory also lead to well-formed logical formulae representing situations of possibility and necessity. In this way, his developments reach such a point that they allow presenting usual experimental results in reasoning tasks as conclusions of deductions from logical formulae following the rules and requirements of system $\mathrm{K}$, and all of this in a manner absolutely compatible with the essential assumptions of the mental models theory.

As far as the frameworks based upon probability logic are concerned, it can be said that, certainly, there are also some proposals, such as, for example, that of Douven et al. (2018, p. 52-53), trying to relate such frameworks to certain philosophical theories and even to essential theses of the mental logic theory, which, as indicated, is one of the approaches supporting the idea of a mental logic.

There is no doubt that this could be an interesting research direction. However, the literature, as it can be checked in many of the works cited here, reports constant discussions about what the mental models theory and the approaches based on probability share and what differentiate them, and perhaps such discussions could help as well.

Nevertheless, a very clear point that can be seen in $\delta$ - $p$ is that, if it is possible to assume that $\mathrm{P}(\mathrm{I}$ am in Europe $\mid \mathrm{I}$ am in Belgium) has to be equal to 1, that means that it is not possible to think about the opposite situation, that is, about the situation corresponding to model [IX]. This is clearly a link to the mental models theory, since it relates the result of a probabilistic calculation to the possibility of affirming (or, in the case of [IX], denying) an iconic model. But, if $\delta-p$, by virtue of a calculation such as $\mathrm{P}(\mathrm{I}$ am in Europe $\mid \mathrm{I}$ am in Belgium) and a model such as [IX], can be linked to the mental models theory, then it can also be related to the theories supporting a mental logic, since models, as indicated above, can be in turn related to rows in truth tables and to possible worlds in a system such as K. In other words, the highest probability (1) in some probabilistic calculations causes certain iconic models to be rejected. However, given that it is possible to build logical formulae from iconic models in different 
ways, probability can be clearly linked to logical forms too (for example, leading to negate those corresponding to models that should be removed).

From all this, and paying attention to the current panorama in cognitive science and the recent proposals about language and reasoning, one might think that there are two possibilities.

The first one is to try to discover different elements in the theories that confirm one of them and refute the other ones. This basically consists of looking for distinct predictions in order to check which of the theories has a greater empirical support. Perhaps this is exactly what is usually done in the literature. Nevertheless, as it can be seen in most of the works cited above, the success in this task is often relative.

The other possibility is to attempt to find links between the theories. The aim would be in this case to review whether they can be joined or they are incompatible and really present different descriptions of the intellectual activity. As said, and that is one of the main points of this paper, there are pieces of evidence suggesting that each theory only focus on one particular aspect of that activity, that particular aspect being absolutely compatible with the other particular aspects considered by the other theories. Therefore, it can make sense to continue in this direction.

This last possibility is, in fact, the one followed in papers such as those of López-Astorga $(2015,2018)$ and the one that has been considered here too. And, taking everything that has been shown into account, it seems that it can be interesting to go on with it. Certainly, decades of theoretical discussions and carrying out experiments to try to find support for a theory and data refuting the other ones do not appear to have obtained relevant results. So, perhaps the best line is precisely the one proposed by López-Astorga, even if, in the course of the research and the analysis, it is necessary to qualify certain points, to soften certain requirements, or to reformulate certain aspects of the theories. It is worth at least trying this task, since, if achieved, the success will be clearly advantageous in several areas of knowledge. Furthermore, and that is a conclusion of this paper that should be highlighted once again, it has been shown above that, at least as far as the analytic sentences are concerned, the three kinds of theories seem not to be incompatible, which enables to think about the possibility to accept the three ones at the same time.

This paper is a result of the Project CONICYT/FONDECYT/REGULAR/FOLIO No 1180013, "Recuperación de las formas lógicas de los enunciados a partir de un análisis de las posibilidades semánticas a las que hacen referencia", supported by the National Fund for Scientific and Technological Development (FONDECYT, following its initials in Spanish), Government of Chile.
1 Adams, E. W., 1975. The Logic of Conditionals. Dordrecht: Reidel. https://doi. org/10.1007/978-94-015-7622-2

2 Bennet, J., 2003. A Philosophical Guide to Conditionals. Oxford: Oxford University Press. https://doi. org/10.1093/0199258872.001.0001

3 Braine, M. D. S. and O'Brien, D. P., 1998a. A theory of if: A lexical entry, reasoning program, and pragmatic principles. In:
Mental Logic, (eds.) Braine, M. D. S. and

References
Associates, Inc., Publishers, pp. 199-244.

4 Braine, M. D. S. and O'Brien, D. P. (eds.), 1998b. Mental Logic. Mahwah: Lawrence Erlbaum Associates, Inc., Publishers.

5 Douven, I., Elqayam, S., Singmann, H., and Wijnbergen-Huitink, J., 2018. Conditional and inferential connections: A hypothetical inferential theory. In: Cognitive Psychology,
Conclusion 
no 101, pp. 50-81. https://doi.org/10.1016/j. cogpsych.2017.09.002

6 Evans, J. St. B. T., Handley, S. J., and Over, D. E., 2003. Conditionals and conditional probability. In: Journal of Experimental Psychology: Learning, Memory, and Cognition, no 29(2), pp. 321-335. https://doi. org/10.1037/0278-7393.29.2.321

7 Henlé, M., 1962. On the relation between logic and thinking. In: Psychological Review, no 69, pp. 366-378. https://doi.org/10.1037/ h0042043

8 Johnson-Laird, P. N., 2010. Against logical form. In: Psychologica Belgica, no 50(3/4), pp. 193-221. https://doi.org/10.5334/pb-503-4-193

9 Johnson-Laird, P. N., 2012. Inference with mental models. In: The Oxford Handbook of Thinking and Reasoning, (eds.) Holyoak, K. J. and Morrison, R. G. New York: Oxford University Press, pp. 134-145.

10 Johnson-Laird, P. N., Khemlani, S., and Goodwin, G. P., 2015. Logic, probability, and human reasoning. In: Trends in Cognitive Sciences, no 19(4), pp. 201-214. https://doi. org/10.1016/j.tics.2015.02.006

11 Kant, I., 1998. The Critique of Pure Reason. P. Guyer \& A. W. Wood (trans.). Cambridge: Cambridge University Press. https://doi. org/10.1017/CB09780511804649

12 Khemlani, S., Byrne, R. M. J., and JohnsonLaird, P. N., 2018. Facts and possibilities: A model-based theory of sentential reasoning. In: Cognitive Science, no 42(6), pp. 18871924. https://doi.org/10.1111/cogs. 12634

13 Krzyzanowska, K., Collins, P. J., and Hahn, U., 2017. Between a conditional's antecedent and its consequent. Discourse coherence vs. probabilistic relevance. In: Cognition, no 164, pp. 199-205. https://doi.org/10.1016/j. cognition.2017.03.009

14 López-Astorga, M., 2015. The disjunction introduction rule: Syntactic and semantic considerations. In: Pragmalingüística, no 23, pp. 141-149. https://doi.org/10.25267/ Pragmalinguistica.2015.i23.08
15 López-Astorga, M., 2018. Iconic representations, possible worlds, and system K. In: Analele Universitatii din Craiova, Seria Filosofie, no 42(2), pp. 120-136.

16 Oakhill, J. and Garnham, A. (eds.), 1996. Mental Models in Cognitive Science. Essays in Honour of Phil Johnson-Laird. Hove: Psychology Press.

17 O'Toole, R. R. and Jennings, R. E., 2004. The Megarians and the Stoics. In: Handbook of the History of Logic, Volume 1. Greek, Indian and Arabic Logic, (eds.) Gabbay, D. M. and J. Woods, J. Amsterdam: Elsevier, pp. 397-522. https://doi.org/10.1016/S18745857(04)80008-6

18 Over, D. E., Hadjichristidis, C., Evans, J. St. B. T., Handley, S. J., and Sloman, S. A., 2007. The probability of causal conditionals. In: Cognitive Psychology, no 54, pp. 62-97. https://doi.org/10.1016/j. cogpsych.2006.05.002

19 Ramsey, F. P., 1931. The Foundations of Mathematics and Other Logical Essays. London: Routledge \& Kegan Paul.

20 Récanati, F., 2000. Oratio Obliqua: An Essay on Metarepresentation. Cambridge: The Massachusetts Institute of Technology (MIT) Press.

21 Rips, L. J., 1994. The Psychology of Proof: Deductive Reasoning in Human Thinking. Cambridge: Massachusetts Institute of Technology (MIT) Press.

22 Stalnaker, R., 1968. A theory of conditionals. In: American Philosophical Quarterly Monograph Series, no 2, pp. 98-112.

23 Stalnaker, R., 1975. Indicative conditionals. In: Philosophia, no: 5, pp. 269-286. https://doi. org/10.1007/BF02379021

24 Wason, P. C., 1966. Reasoning. In: New Horizons in Psychology, (comp.) Foss, B. Harmondsworth (Middlesex): Penguin, pp. 135-151. 
Miguel López-Astorga. Analitiniai sakiniai, pažinimas ir kalba: šiuolaikinių teorijų sąsajos Šiame straipsnyje analizuojami galimi triju šiuolaikinių teoriju apie pažinimą ir kalbą ryšiai bei skirtumai. Nagrinejjamos šios teorijos: paremiančiosios požiūri, kad mąstymo logika egzistuoja, protinès veiklos modeliu teorija ir tikimybių logika grindžiami sisteminiai požiūriai. Parinkti analitiniai sakiniai nagrinejami pasitelkus visų minètu tipų teorijas. Remiantis tyrimo rezultatais galima teigti, kad, taikant triju minètų tipu teorijas, sakiniai nagrinejjami panašiai, ir tai rodo, kad šios teorijos gali būti susijusios labiau nei manyta. Todèl argumentuojama, kad triju tipu teorijas galima būtų taikyti vienu metu, o teoriju skirtumu analizè leidžia teigti, kad jos paliečia skirtingus kalbos ir pažinimo aspektus. Verta pažymèti, kad panašus požiūris i tris minètąsias teorijas jau buvo išreikštas literatūroje (ypač nemažai nustatyta mąstymo logiką paremiančiu teoriju ir protinès veiklos modelių teorijos sąsaju). Vis dèlto šiame straipsnyje pateikiami dvejopi pastebejjimai: pirma, ryšys tarp nagrinèjamuju teoriju aptariamas iš kitokios - analitiniu sakinių - perspektyvos; antra, ižvalgos apie ryšius tarp triju teoriju pateikiamos iš tos pačios perspektyvos ir nuosekliai.

\section{Miguel López-Astorga}

\section{Research interests}

Philosophy of language, cognition, epistemology, logic

\section{Address}

Instituto de Estudios Humanísticos, Universidad de Talca. Av. Lircay s/n, 3460000 Talca, Chile

\section{E-mail}

milopez@utalca.cl 